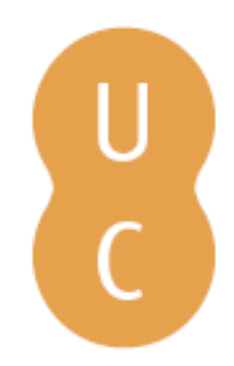

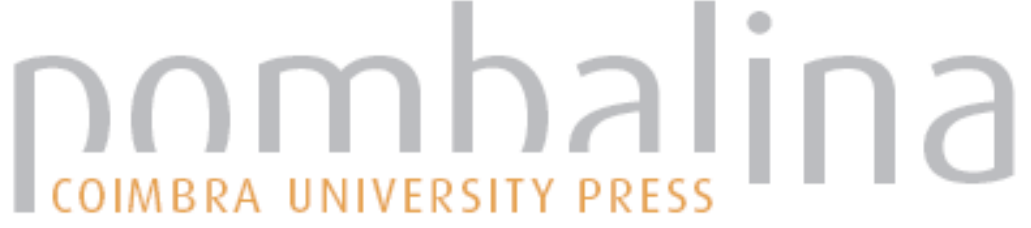

\section{Ética e Estética: Sobre a Poesia após Auschwitz}

Autor(es): Jesus, Paulo; Jesus, Maria Helena F.

Publicado por: Imprensa da Universidade de Coimbra

URL persistente:

URI:http://hdl.handle.net/10316.2/43577

DOI:

DOI:https://doi.org/10.14195/978-989-26-1380-2_4

Accessed : $\quad$ 26-Apr-2023 10:38:35

A navegação consulta e descarregamento dos títulos inseridos nas Bibliotecas Digitais UC Digitalis, UC Pombalina e UC Impactum, pressupõem a aceitação plena e sem reservas dos Termos e Condições de Uso destas Bibliotecas Digitais, disponíveis em https://digitalis.uc.pt/pt-pt/termos.

Conforme exposto nos referidos Termos e Condições de Uso, o descarregamento de títulos de acesso restrito requer uma licença válida de autorização devendo o utilizador aceder ao(s) documento(s) a partir de um endereço de IP da instituição detentora da supramencionada licença.

Ao utilizador é apenas permitido o descarregamento para uso pessoal, pelo que o emprego do(s) título(s) descarregado(s) para outro fim, designadamente comercial, carece de autorização do respetivo autor ou editor da obra.

Na medida em que todas as obras da UC Digitalis se encontram protegidas pelo Código do Direito de Autor e Direitos Conexos e demais legislação aplicável, toda a cópia, parcial ou total, deste documento, nos casos em que é legalmente admitida, deverá conter ou fazer-se acompanhar por este aviso. 


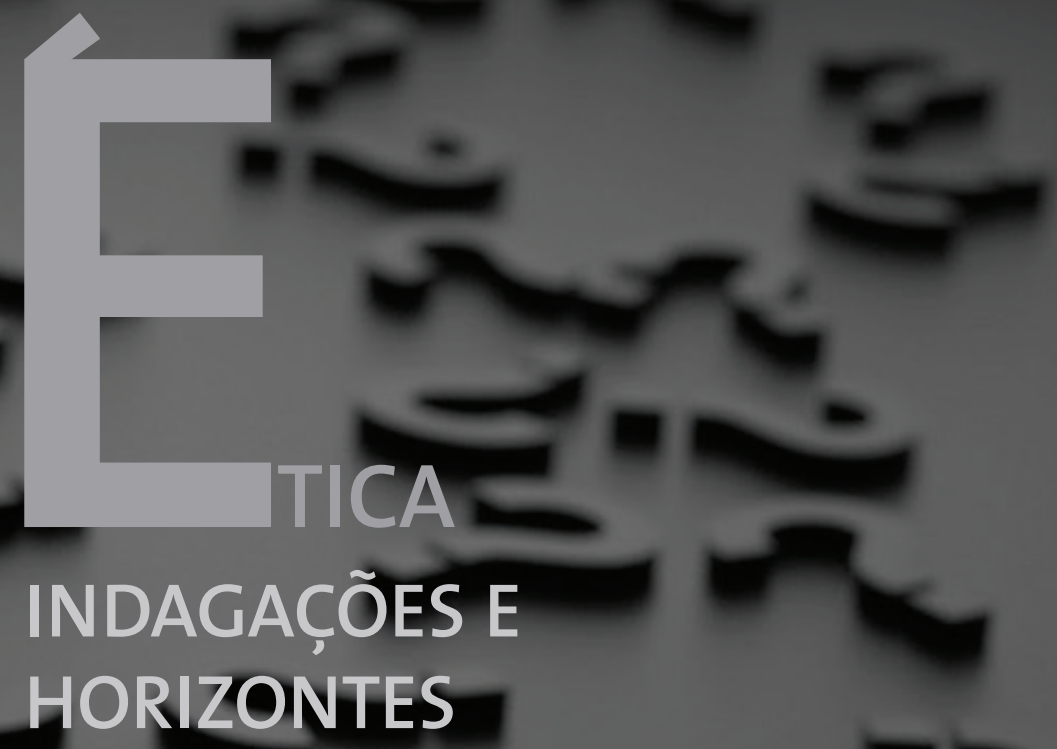

Maria Formosinho Paulo Jesus Carlos Reis (Coord.)
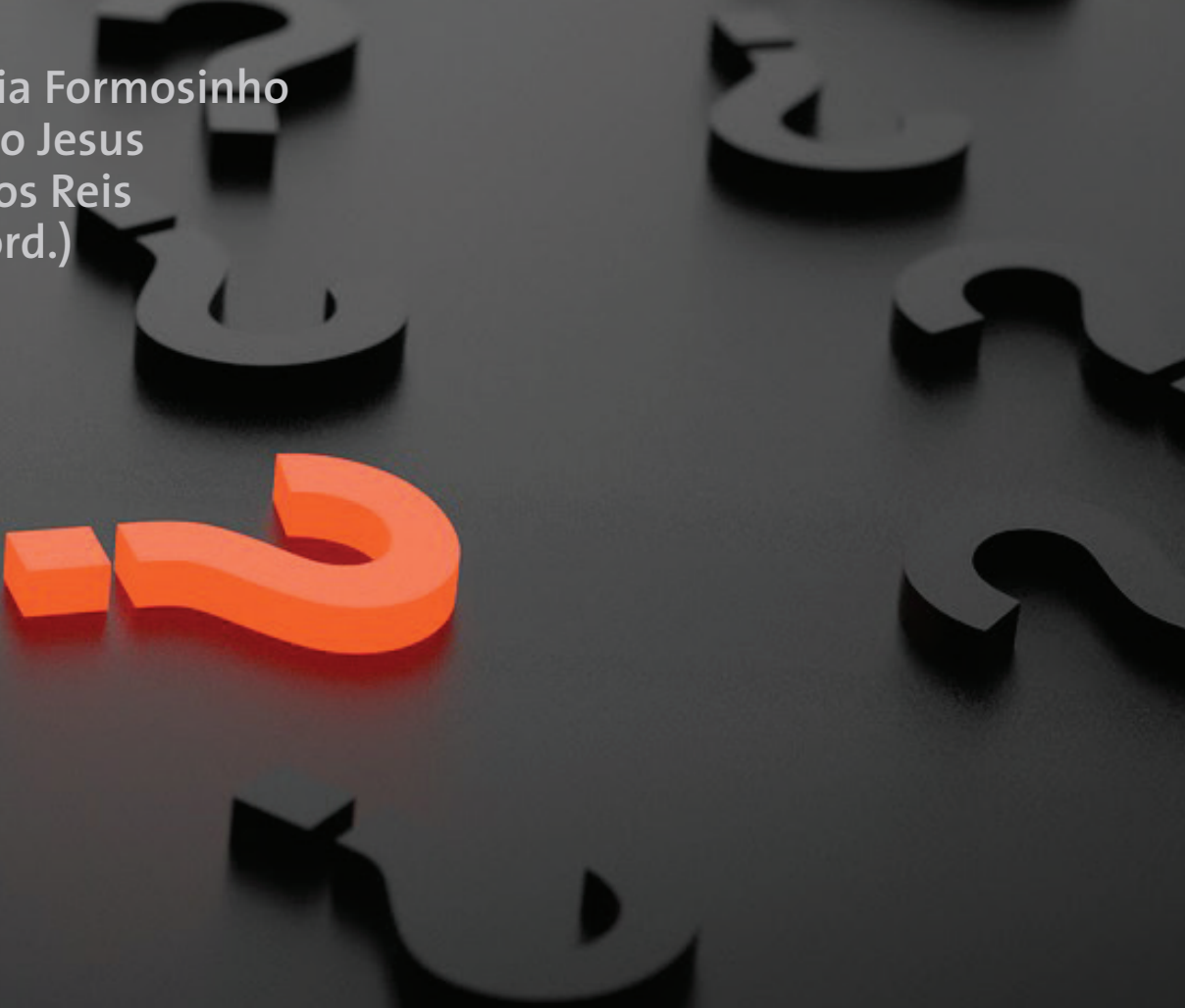


\section{CAPÍTULO IV}

\section{ÉTICA E ESTÉTICA: \\ SOBRE A POESIA APÓS AUSCHWITZ}

Paulo Jesus $^{1}$ e Maria Helena F. Jesus ${ }^{2}$

\section{Introdução: Entre esteticismo amoral e moralismo estético}

A relação entre Ética e Estética é essencialmente ambígua e equívoca, assumindo configuraçóes contrastantes que se situam entre dois polos opostos. Num extremo, encontra-se o esteticismo autotélico e autónomo da "Arte pela Arte", que defende o carácter amoral e apolítico da criação artística, a sua indiferença ou neutralidade total face ao Bem e ao Mal. No outro extremo, vigora o comprometimento moral e moralizador que transforma a Arte em instrumento de ação ético-política e interpreta todas as obras estéticas como ações humanas com significado moral, incarnando sempre uma axiologia concreta, realizando ou interrogando sempre, essencialmente — volens nolens —, um ideal moral, um projeto de existência humana e uma forma de vida no mundo, orientandose para um horizonte utópico: um desejo de Novo.

Assim, as duas posiçôes tendem a ser formalmente irreconciliáveis. Numa Estética da Obra pura, toda a arte que serve uma ideia ética ou política aliena-se, destrói-se e nega-se a si própria. Para uma Estética da Açấo histórica, constitutivamente produtora de "valor", onde se funde o estético (a forma bela), o cognitivo (a compreensáo do real), o ético (a opçáo pelo bem) e o político-social (o projeto inovador de "homem"), a própria ideia de Arte como criaçáo de mundo autorregulado, num claustro de ser-em-si-e-para-si, exprimiria um eclipse da consciência axiológica, um alheamento da dinâmica de construçáo de sentido e de projeto existencial, caraterístico de toda a ação humana e, no limite, derivaria de uma tendência niilista. Esta

\footnotetext{
${ }^{1}$ Centro de Filosofia da Universidade de Lisboa (CFUL) e Universidade Portucalense (UPT).

${ }^{2}$ Centro de Literaturas e Culturas Lusófonas e Europeias, Universidade de Lisboa (CLEPUL).
} 
polarização revela a dificuldade de articulação crítica entre o princípio de liberdade estética e o princípio de responsabilidade moral, devido a uma falsa conflitualidade entre, por um lado, o gesto lúdico e poiético da Arte e, por outro, a ancoragem da sua criatividade livre num mundo vital estruturado por relaçôes simbólicas. Com efeito, o princípio de liberdade que anima a vida estética na sua criatividade transfiguradora e transgressiva não possui uma força absoluta nem infinita, capaz de se causar a si própria e de operar ex nibilo. Ao invés, toda a Poiesis artística se nutre de liberdade e de historicidade, construindo formas que se inscrevem na trama histórica das açôes, das matérias e dos símbolos humanos (Giowacka \& Boos, 2002). Cada gesto estético e cada obra artística emergem da história e exprimem uma fulguração histórica inovadora que destrói e constrói mundo, que encadeia e rompe sentido, manifestando uma eficácia criadora que transcende o livre jogo da imaginação produtiva no seu atelier, solitário ou multitudinário. Essa eficácia criadora tem o poder de produzir e de significar: atualiza uma interpretação do mundo e, assim, declara uma posição teórica e prática sobre a textura do mundo onde se inscreve, transformando algo dessa textura simbólica (os modos de fazer sentido), axiológica (os modos do valor) e ética (os modos do bem). O gesto artístico acontece e age no mundo, com e contra a sua materialidade de mundo vivo e vivido. A operaçáo poiética é uma açấo significativa situada num sistema semântico relacional, ou seja, na trama da história, e uma ação cuja significação se define pela dialética entre a sua situação-na-história e a sua projeção-na-história.

A liberdade estética pratica-se e realiza-se dentro dos limites do mundo real das relaçóes humanas e da história das linguagens e dos símbolos. A arte é sempre processo de devir-corpo e devir-mundo e, portanto, descobre-se material e corporalmente confinada, mas capaz de virtualizaçáo e de abertura, mediante a ação hermenêutica e pragmática sobre o mundo, como imaginação imaginante de mundos possíveis, cuja alteridade "irreal" ou "sobrerreal" está (in)contida na própria potencialidade "ainda-não-expressa" do real. A liberdade estética deve exprimir um mundo potencial e responder eticamente pelo projeto de existência que injeta na matéria relacional e simbólica do mundo. Historicamente situada, a ação estética implica a partilha de responsabilidade pela eficácia histórica da sua açáo. Portanto, sem sacrificar a autonomia criativa da Arte, que é sua condição de possibilidade, e sem reduzir a Arte a um instrumento de intervençáo sociopolítica ou a uma estratégia psicopedagógica de formação cívico-moral, a experiência estética - tanto de criação como de fruição — apela a uma vivência reflexiva que assume responsabilidade pela produçáo do Novo e dos signos inovadores que realizam poeticamente o que significam: novos sentidos e novas experiências de ser-na-história. Cada novidade estética transporta consigo uma nova forma de invenção e de habitação do mundo, isto é, uma atitude fundamentalmente ética.

Neste capítulo, pretendemos aprofundar o sentido da liberdade poiética e estética enquanto responsável por si própria e pela produção de significado 
que injeta no mundo histórico, não só perseguindo e interpretando a intriga do real vivido, mas também imaginando, explorando e quasi-habitando outros mundos semanticamente possíveis. Num primeiro momento, reavaliaremos a atitude polémica de T. Adorno que, provocadoramente, afirma ser bárbaro haver poesia após a mutação da civilização em barbárie, simbolizada por Auschwitz. Nesta reavaliação, interrogaremos a estreita relação entre estética e pathos, mostrando, pela reflexão metapoética de P. Celan, como a estética pode ser hipersensível às catástrofes da dor - figura heterogénea do mal na intimidade da vida vivida. Num segundo momento, questionaremos a experiência ética que acompanha a Arte Poética, através de algumas vozes da poesia portuguesa contemporânea, nomeadamente Sophia M. B. Andresen que reconhece um imperativo moral na prática poética e artística em geral: o imperativo da "inteireza do ser" e da coerência harmónica entre Beleza, Bondade, Verdade e Justiça.

\section{Adorno: Como escrever um poema depois de Auschwitz?}

Tornou-se uma declaração corrente, dizer que Theodor Adorno consideraria impossível escrever poesia depois de Auschwitz. Descontextualizadas, as palavras de Adorno sáo, por certo, desconcertantes. Porém, integradas no fluxo argumentativo do ensaio "Crítica cultural e sociedade" (1949), essas palavras situam, num mesmo plano de reificação necrófila, a barbárie de Auschwitz e a ansiedade pela reinvenção pacífica e pacificadora da cultura no pós-guerra. Face à queda abissal do humano civilizado, hiper-racional e burocratizado, homo insipiens sapientissimus, Adorno pressente uma qualidade intensiva de não-retorno, uma metamorfose antropológica, uma interrupção da Poiesis onde o homem se faz e refaz continuamente entre o Belo e o Bem. O pressentimento cético de Adorno vislumbra uma negação qualitativa do humano pela história e, portanto, uma resposta tragicamente suspensa às questóes de possibilidade: Que possibilidade de Cultura depois da degenerescência total da cultura em barbárie? Que possibilidade de passagem da dialética negativa de barbarização, onde submergiu o homem das civilizações, para a Cultura restauradora do humano? O espírito que desceu à reificação do humano inumou a sua própria humanidade e corrompeu, talvez irreversivelmente, a sua capacidade de (re)humanização. Portanto, talvez todos os poemas depois de Auschwitz tenham sabor a gás e a cinza, talvez a própria Arte e a própria Cultura se tenham gaseificado e carbonizado definitivamente nas câmaras desse campo onde todo o húmus se fecundou de matéria orgânica pós-antropológica.

"Escrever poesia depois de Auschwitz é um ato bárbaro" que prolonga a barbárie e cuja barbaridade mais profunda reside na auto-ignorância da sua essência bárbara, como Adorno sugere: 
Quanto mais totalitária for a sociedade, tanto mais reificado será também o espírito, e tanto mais paradoxal será o seu intento de escapar por si mesmo da reificaçấo. Mesmo a mais extremada consciência do perigo corre o risco de degenerar em conversa banal. A crítica cultural encontra-se diante do último estádio da dialética de cultura e barbárie: escrever poesia depois de Auschwitz é um ato bárbaro, e isto corrói até o conhecimento da razão pela qual hoje se tornou impossível escrever poesia. A reificação absoluta, que pressupunha o progresso do espírito como um dos seus elementos, está a preparar-se para absorver inteiramente o espírito. A inteligência crítica não é capaz de enfrentar este desafio enquanto se confinar a si própria numa contemplação auto-suficiente (Adorno, 1981, p. 34).

Depois de Auschwitz, toda a Poesia, toda a Cultura e toda a Crítica Cultural gravitam em torno do abismo interior da sua impossibilidade, porque, no interior dos seus atos e das suas operaçóes, trabalha a força técnica totalitária que concebeu, construiu e monitorizou "Auschwitz", esse Logos holocáustico que consome todo o humanismo dos operadores e das operaçóes para converter o espírito, a vida, o valor em processos de coisas (Cohen, 2005). O objeto imediato deste texto era a reprovação da cumplicidade da crítica cultural com a máquina reificadora do nazismo e do comunismo, celebrando hipocritamente as virtudes da cultura tradicional dos povos. Em Adorno, manifesta-se a suspeita de vacuidade patética contra a reconstrução da Cultura depois da Barbárie e a denúncia do veneno que a arte e a crítica cultural podem constituir quando coniventes com um sistema sociopolítico instaurador de barbárie e, também, quando inebriadas por uma palingenesia cultural que desconhece a continuidade da tessitura bárbara.

Para Adorno, toda a Cultura e toda a Crítica cultural careceram, dentro do sistema totalitário e dentro do entusiasmo do renascimento pós-totalitário, de verdadeiro criticismo, com mácula indelével de culpa e responsabilidade pró-totalizante pela sua imersão acrítica no processo histórico da barbárie. O sistema cultural e o sistema político totalitário tendem a exprimir-se harmonicamente, apesar da sua relativa independência recíproca, co-produzindo, na estrutura da polis, a cultura da barbárie, silenciando a possibilidade de inovação histórica, neutralizando as forças de dissidência, resistência, rutura, desobediência civil, objeção de consciência, ação-revolução polifónica. A Cultura é responsável pela sua (im)possibilidade, isto é, pela sua liberdade e pela sua alienação. Escrever um poema é bárbaro, se este carecer de radical poieticidade, de relação espontânea com a sua matéria existencial, aquela liberdade livre que ataca a doação hereditária do real com a projeção laboriosa do possível e desestabiliza a semântica cristalizada da história real com a semântica ígnea do ainda-absurdo ou ainda-alógico da história dos mundos possíveis. O criticismo exige dialeticidade: "Uma crítica dialética da cultura deve, simultaneamente, participar e não participar na cultura. Só então fará justiça ao seu objeto e a si própria” (Adorno, 1981, p. 33). Sem iconolatria 
e sem iconoclastia, a crítica dialética deve mostrar a intimidade genética entre cultura e barbárie, mas salvando a irredutibilidade e a incomensurabilidade que permite discernir, contra o Thanatos divisor e regressivo, o Eros re-vitalizador e re-civilizador (Marcuse, 1998), enquanto criatividade imaginativa que mantém os seus sujeitos inobjetiváveis, capazes de interrogação metafísica e anti-metafísica, através da inquietude de todos os seus objetos que questionam o sentido e o absurdo da história, resistindo ao mesmo tempo ao poder do infra-racional e do supra-racional. O primeiro insinua-se na experiência dos confins da razão, que promove a paralisia alienada de náo-compreender, e o segundo trabalha para a domesticaçáo ideológica da razáo e convida, diante do êxtase ou do horror, à comunhão consoladora com uma verdade insondável.

A "crítica dialética", explorada por Adorno, é um ethos vocacionalmente livre e libertador, uma terapia ética que regenera o primeiro dever-ser da razáo, o dever de criticar, e agudiza a sensibilidade face ao não-sentido (Bernstein, 2001). O sujeito ético, vinculado à vitalidade e universalidade do humano, emerge na prática da crítica dialética, devido à sua eficácia fundadora da experiência de reflexão e de relação inter-humana, no interior concreto da vida e para a vida. A crítica não é um momento lógico da Verdade, mas o espaço vibratório, instável, onde a Verdade se reconhece como Ideia e abdica do seu império vazio, não para ceder a sua autoridade ao Nada, mas para afirmar o "sentido" como possibilidade vulnerável de labor humano.

Consciente da natureza hiperbólica da sua dúvida sobre a possibilidade de Poesia depois de Auschwitz, Adorno, explica-se na "Lição 14 de Metafísica", assumindo que a sua posição se situa dentro da tensão dialética que contém uma antinomia irresolúvel entre a impossibilidade e a necessidade de vida, de homem e de arte pós-bárbara:

Concederia prontamente que, tal como afirmei que depois de Auschwitz não se podia escrever poemas - fórmula pela qual eu queria indicar que a cultura ressuscitada me parecia oca —, também se poderia dizer que se deve escrever poemas, no sentido da afirmação de Hegel, na sua Estética, que enquanto houver consciência do sofrimento entre os homens, deve também existir arte como forma objetiva dessa consciência. Deus sabe que não pretendi resolver esta antinomia nem posso pretendê-lo pela simples razão de que a minha própria tendência me impele em favor da arte que, erroneamente, me censuram de querer reprimir. Nalguns jornais da Alemanha de Leste, afirmou-se mesmo que eu me tinha declarado contra a arte e adotado, desse modo, a atitude da barbárie. Porém, deve-se colocar ainda outra questão: se se pode viver depois de Auschwitz. É uma questão metafísica, embora tenha na base a suspensão da metafísica. De facto, é estranho como todas as questóes que negam e desertam a metafísica assumem, precisamente por isso mesmo, um carácter estranhamente metafísico. Esta questão surgiu-me a mim próprio, nos pesadelos recorrentes que me perseguem, em que sinto que já não sou eu que 
vivo realmente, mas que sou somente a emanação do desejo de uma vítima de Auschwitz. [...] Dado que se refere à possibilidade de uma afirmação da vida, esta questão não pode ser eludida. Tendo a crer que qualquer pensamento que não se meça com este padrão, que não o assimile teoricamente, afasta à partida o que o pensamento deveria enfrentar - e assim nem sequer pode ser chamado pensamento. (Adorno, 2000, pp. 110-111)

A “era de Auschwitz", isto é, o mundo histórico em sinergia com as forças que Auschwitz incarna (o mundo da bomba atómica e do suicídio planetário, o mundo da racionalização tecnocientífica da possível morte gratuita, morte vazia de experiência para o eu-moribundo), suspende toda a Cultura diante da sua autocontradição de monstro autofágico. Assim, na própria possibilidade de Auschwitz, evidencia-se a barbárie interna ao espírito, que esterilmente desuniu sujeito e objeto, e altera-se o modo da insignificância do humano: não mais a finitude aberta, sensibilidade auto-afetiva, que definia o homem-síntese de Atenas e Jerusalém, mas a neutralidade massiva do humano húmus, matéria indiferente entre a matéria, corpo anónimo torturável até à cinza, experiência propriocetiva da desvitalização da vida e das realizaçóes simbólicas (Henry, 2004). Poderá haver "poesia" (isto é, vida humana "valendo" como humana) depois de Auschwitz? Poderá a vida ser "valor" e "razão" depois de Auschwitz? Valerá viver (valerá poetizar e ser)? Ou ser-e-não-ser se fundirá "sem-valor"? Adorno recusa suicidar-se, como inteligência e como corpo vitalmente unos; recusa também as ideologias metafísicas e recusa o fim do desejo de metafísica donde emergem as razóes de viver.

Se "ser-depois-de-Auschwitz" simboliza uma paisagem carbonizada inabitável, holocausto de toda a linguagem e de todo o sentido, num regresso da carne ao pó, até à combustão do inorgânico, autossacrifício mudo sem apocalipse de novos céus e nova terra; e se "escrever poesia" simboliza o esforço e o cuidado partilhado pela continuidade de uma aliança, sempre renovada e frágil, entre viver e significar; então, "ser-depois-de-Auschwitz" é "ser-sem-escrita”, é carência absoluta de significar num mundo sem signos, ou seja, sem mediação entre ser e viver. Portanto, "escrever poesia depois de Auschwitz" é uma experiência impraticável: respirar num caos sem atmosfera. A Cultura devém Barbárie através da sua clausura autárquica num sistema de significantes sem significado, em que a vida se ausenta, sob a sua máscara funerária. A crise bárbara da cultura transforma tudo em ideologia ou lixo: "Toda a cultura depois de Auschwitz, incluindo a sua crítica urgente, é lixo." (Adorno, 2005, p. 267). Daí a antinomia teórica e o dilema ético: "Quem defender a manutenção de uma cultura radicalmente culpável e medíocre transforma-se em seu cúmplice, enquanto quem negar a cultura incrementa diretamente a barbárie que a nossa cultura demonstrou ser" (Adorno, 2005, p. 267). Noutros termos, "escrever uma nova poesia” é impossível e necessário: uma poesia que devemos, mas não podemos escrever. Depois de "Auschwitz", 
as ciências, as artes, as religióes e todas as arquiteturas virtualmente significantes do mundo são cadáveres mumificados, tecnicamente esvaziados antes da putrefação, antes de serem reconhecíveis como "lixo", tendo-se assim obliterado esse estádio crítico, conscientizador, ético e pedagógico, da experiência da decomposição nauseabunda da cultura. Que produção de cultura, que Poiesis ou que poema, poderá revitalizar a espontaneidade da vida sensível? O homem que, de modo contingente, sobrevive à barbárie deve com honestidade existencial saber reconhecer o que transporta um "poema autêntico" — um ato de sentido — da era pós-bárbara: o contacto com o seu lugar vazio, transmutando o impossível em necessidade: carência (quasi-fisiológica) ou desejo de "escrita biopolítica", imperativo de esperança, dever absoluto de não-repetição de Thanatos bárbaro. Pensar a necessidade desta escrita biopolítica é afirmar a vida-para-a-vida diante dessa possibilidade impossível, possibilidade impossibilitadora de toda a possibilidade, que continua sendo "Auschwitz" ou "Hiroshima" como morte prática de "Deus", isto é, morte da força humana de imaginar e habitar horizontes de sentido com hospitalidade universal. O "princípio esperança” (Bloch, 1995) e o "princípio responsabilidade" (Jonas, 1984) cruzam-se na poesia impossível que devemos aprender a escrever para que a vida se firme na vida.

Na obra do poeta e ensaísta Paul Celan (1920-1970) desenvolve-se e experimenta-se uma prática poética onde se procede à ancoragem da poesia na vida atravessada pela catástrofe e pelas trevas do Holocausto, gaseificação e carbonização fatal da Cultura pela Cultura. Todos os ramos da árvore da Cultura se transformam em instrumento de tortura, tripallium. As conquistas da Ciência e da Técnica, as subtilezas da Filosofia, os êxtases da Arte e da Religião... tudo trabalha nos fornos e chaminés de Auschwitz. O que poderá ser a Poesia, de dentro da experiência-limite da perda do humano e de dentro da língua onde se dá o Acontecimento? Essa língua, solo materno e cinza de cadáver, é para Celan e para Klemperer uma matéria ambivalente: a paradoxal língua alemá de elevada literatura e de comando bélico. À imagem de V. Klemperer (2006) que analisa a violência íntima nas articulaçôes da língua alemã, transformada, pelo uso nazi, em Lingua Tertii Imperii, P. Celan enraíza-se na lírica alemã e no prisma particular da sua boca ferida pelo sofrimento do povo dos seis milhóes de singularidades dolorosas para o qual haveria de dizer-se, naquela língua, o eufemismo bárbaro de uma "solução final" (Endlösung). Nesta língua, com a qual e contra a qual, Celan sobrevive poeticamente, "Auschwitz" significa a eficiência sociotécnica da pragmática que deriva de uma Weltanschauung imperial e marcial e reconfigura as conexôes sintáticas e semânticas da língua quotidiana, tornando-a inquietante e traumatizante (Nader, 2007).

Emergindo da experiência dessa inquietação mortífera, a Poesia afirma-se como sendo a vida que reanima a Língua, a própria vitalidade da vida, a liberdade vitalizadora da vida, mas sempre íntima do absurdo da História dentro do silêncio da língua quebrada, absurdo e silêncio que são constitutivos da experiência (Caygill, 
2006; Lacoue-Labarthe, 2004). A Poesia experimenta uma salvação frágil da Língua, estabelecendo uma relação vital com a alteridade e a ipseidade da existência, abrindo a Possibilidade da palavra que atravessa o fundo do abismo e interroga o sentido da sua própria travessia, numa interrogação que toca o fundo da "significação" e da "realidade", buscando algo, clamando por alguém, ninguém, um tu, uma terra onde fundar a abertura da errância à esperança indefinida, pós-carbonização. Para Celan, portanto, a violência da "experiência” imprime-se e repete-se na língua que clama por Outro: "O einer, o keiner, o niemand, o du" (verso tragicamente apelativo sem interlocutor capaz, do poema "Es war Erde in ihnen" do livro Niemandsrose, 1963). A Poesia seria a possibilidade de um labor messiânico, radicalmente lúcido e ingénuo, que crê e descrê de si próprio. Escrita da vida, a Poesia é a imersão apropriativa do acontecimento de perda abissal, através do movimento de travessia sem retorno, que desenha um meridiano religando os polos terrestres, animado pelo desejo e pela melancolia diuturna de encontro. A matriz do poema afigura-se, assim, dialógica e afónica, heurística e erótica, utópica e zetética:

Acessível, próxima e não perdida permaneceu, no meio de todas as perdas, apenas isto: a língua. Ela, a língua, permaneceu não perdida, sim, apesar de tudo. Mas teve então de atravessar as suas próprias ausências de resposta, atravessar um terrível mutismo, atravessar as mil trevas de palavras portadoras de morte. Ela atravessou tudo isso e náo teve palavras para o que aconteceu, mas atravessou o próprio acontecimento. Atravessou e pôde regressar à luz enriquecida com tudo isso.

Nesta língua procurei, durante esses anos e durante os anos que se seguiram, escrever poemas: para falar, para me orientar, para saber onde me encontrava e para onde me chamavam, para projetar realidade diante de mim.

Era, sem dúvida, apropriação, movimento, caminhada; era a busca de uma direção. E se me interrogo sobre o seu sentido, então parece-me ter de dizer que na minha questão aborda também a questão do sentido dos ponteiros do relógio. Pois, o poema não está fora do tempo. Ele visa, evidentemente, o infinito, procura passar através do tempo - através e não por cima dele.

O poema pode, dado que é um modo de aparição da linguagem e, como tal, dialógico por essência, ser uma garrafa no mar, lançada à água com a crença, nem sempre com muita esperança, que pudesse num certo lugar e tempo, ser levada para uma terra, terra-coraçáo [Herzland] talvez. Deste modo, os poemas também estão a caminho: vão numa direção. Para onde? Para algo que se mantém aberto, disponível, talvez para um tu, um tu a quem falar, uma realidade a quem falar (Celan, 2002, pp. 56-57).

Inscrito na finitude temporal da história, o poema manifesta a Poesia sobrevindo e sobrevivendo ao Acontecimento, como cinza paciente que talvez repouse e, senão for irreversivelmente estéril, frutifique outra Terra ou outro Desejo de ser-na-terra (Bambach, 2013). Na incerteza do caminho, a verdade da Poesia e 
do poema acontece na redação do tempo e do corpo próprio, concentrado nas "mãos verdadeiras" laboriosas:

$\mathrm{O}$ artesanato (Handwerk) pertence às mãos. E as mãos, por seu turno, pertencem a um homem único, isto é a uma alma única e mortal, que com a sua voz e sem voz procura um caminho. Só mãos verdadeiras escrevem verdadeiros poemas. Não vejo nenhuma diferença de princípio entre um aperto de mão e um poema. (Celan, 2002, p. 44)

A produção de verdade através do poema realiza-se no reconhecimento da unicidade validada pelo vigor partilhado de um "aperto de mão" imanente ao poema. As mãos que escrevem e reescrevem pressentem a possibilidade de um nó eficaz com o outro-em-mim e o outro-em-si. Um sentido que seria verdadeiramente caminho possível que abre um espaço intercorporal de co-possibilidade e de co-pertença. As mãos que escrevem e as mãos que leem devem tender para paixóes e ficçóes comuns. Desejam-se umas às outras e apoiam-se na colaboração imaginativa do que virá. Sem essa coordenação fantástica das mãos, não é possível poesia neste mundo e, consequentemente, não é possível haver mundo. As mãos oferecem o mundo ao espírito porque tecem as relaçóes cognitivas e espirituais que organizam o mundo como um sistema estável de sentido.

\section{Arte (Po)ética: Unidade do Bem, do Belo e do Verdadeiro}

Numa dimensão mais nacional e menos trágica, o ensaio de Sophia de Mello Breyner Andresen "Poesia e Revolução" (Andresen, 1977) responde às mesmas preocupaçóes de Adorno e Celan. A primeira parte desse ensaio apresenta o poder revolucionário da poesia. Uma poesia caracterizada pela essência fundadora, que busca a inteireza. A segunda parte formula um conjunto de princípios que comprometem o escritor com a Revoluçáo por meio da fidelidade à palavra. Reencontramos aqui, como em Adorno, a mesma crítica de índole marxista, contra a alienação ou desumanização produzida pelo "uso burguês da cultura":

Se queremos ultrapassar a cultura burguesa - ou seja o uso burguês da cultura - é porque vemos nele o reino da divisão, o fracasso do projeto da inteireza. $[\ldots]$

A arte da nossa época é uma arte fragmentária, como pedaços de uma coisa que foi quebrada.

Sou um espalhamento de cacos sobre um capacho por sacudir, disse Fernando Pessoa que aqui, no extremo ocidente, percorreu até aos últimos confins os mapas da divisão e letra a letra os disse.

E caminhar para a frente é emergir da divisão. É rejeitar a cultura que divide, que nos separa de nós próprios, dos outros e da vida. (Andresen, 1977, p. 76) 
A cultura burguesa preocupa-se com a divisão do poder. Nesse sentido, agindo contra natura, essa burguesia instaura um plano cultural que responda às suas necessidades, ignorando a natureza do dizer poético. Ora, a cultura e a poesia não podem ser programadas e idealmente deveriam ser fundadoras de todo e qualquer ato político humanizador. Contradizer esta ordem é caminhar para a barbárie. Segundo a metáfora de Sophia no poema "O rei de Ítaca" de O Nome das coisas, "A civilização em que estamos é tão errada/ Que nela o pensamento se desligou da mão" (Andresen, 2010, p. 631). Caberia à poesia reconciliar estas duas dimensôes: conhecimento e ação, verdade e vida, logos e ergon. Se há meio de salvar o "sentido" do uso burguês da cultura e da palavra, essa salvaçấo depende das mãos verdadeiras que escrevem os poemas verdadeiros. O poeta forma-se como sensibilidade e responsabilidade, atenção e vigilância, num mundo que sofre de fragmentação, desejando re-fundar a sua unidade.

Esta visão re-fundadora da palavra poética está naturalmente em consonância com o Romantismo que dinamizou um movimento impulsivo para colocar a poesia nesse espaço original e sagrado, conferindo-lhe responsabilidade criativa perante a civilização. "Compete à poesia, que é por natureza liberdade e libertação, inspirar e profetizar todos os caminhos de desalienação." (Andresen, 1977, p.77). Inspirar e profetizar os caminhos da desalienação é ser depositário de um estatuto de potencial epifânico: translucidez da inteligibilidade do ser na nomeação do mundo pela língua poética (Jesus, 2014).

Para Sophia, a "Poesia" é o real absoluto; a "poesia" é a arte da criação libertadora e o "poema" é o lugar da aliança amorosa, sempre incompleta e vulnerável, entre o homem e o real (Andresen, 1960). A poesia atende à história e ao pathos dos homens. O poema manifesta uma língua sensível ao verdadeiro, ao bom e ao belo, abraçando o cuidado pela justiça e pela justeza do ser e do estar terrestre. A poética desdobra-se numa existência simultaneamente estética e ética, como nos diz Sophia em "Arte Poética III":

Aquele que vê o espantoso esplendor do mundo é logicamente levado a ver o espantoso sofrimento do mundo. Aquele que vê o fenómeno quer ver todo o fenómeno. É apenas uma questão de atenção, de sequência e de rigor. (Andresen, 2010, p. 841)

Herdeira da arte poética helénica, acolhedora da "manifestação" (fainomenon) e do "des-velamento" (a-letheia) do real, do humano e da sua aliança, atenta à luminosidade e ao sofrimento do homem (Andresen, 1992), Sophia propóe uma Poética do "fenómeno todo", porque a palavra poética desvela e epifaniza uma presença inteira do ser-em-si-para-mim. Articulando Verdade e Bem, a poesia denuncia ou anuncia diversamente: quer de forma alusiva (cantando a liberdade elementar do reino-Poesia com o vento e o mar, contra o Caos da cultura divisora, como se verifica nos livros No Tempo Dividido e Mar Novo), quer de forma brutal (misturando grito e pranto, em nome de uma pátria de 
irrealidade e de exílio, como no livro Grades, integrado em Livro Sexto, ou nos poemas de resistência "Catarina Eufémia" do livro Dual e nalgumas composições de $O$ Nome das Coisas), quer ainda de forma jubilatória (celebrando o advento da revolução, por exemplo os poemas " 25 de Abril", "Revolução", "Revoluçấo-Descobrimento"). Enquanto liberdade e libertação primordiais, a poesia é fundação e fundamento de existência ética e política, regida por um ideal libertador, emergência da Cultura onde a liberdade se manifesta e se atualiza, exigindo e buscando plenitude. Intimamente ligada à construção da subjetividade da alma (psique) e da intersubjetividade da cidade (polis), a Poesia apresenta-se como res publica. Por conseguinte, o Filósofo-rei da República de Platáo deveria ele próprio ser poeta e náo perseguidor de poetas. O poema diz a dimensão plural do mundo, dá testemunho de uma consciência una que atravessa e unifica a amplitude dos polos opostos da existência:

Se em frente do esplendor do mundo nos alegramos com paixão, também em frente do sofrimento do mundo nos revoltamos com paixão. Esta lógica é íntima, interior, consequente consigo própria, necessária, fiel a si mesma. $\mathrm{O}$ facto de sermos feitos de louvor e protesto testemunha a unidade da nossa consciência. (Andresen, 2010, p. 842)

O poema exprime o poeta na sua relação com a Poesia: lugar de fidelidade a si mesmo, de possibilidade de co-presença, de unidade de forças vitais contrárias como o "louvor e o protesto". Forças essas que são necessárias à manifestação plena do humano. A poesia, como modo de vida e "arte do ser", é enriquecida em "Arte poética III" por um poder ético que a acompanha:

E é por isso que a poesia é uma moral. E é por isso que o poeta é levado a buscar a justiça pela própria natureza da sua poesia. E a busca da justiça é desde sempre uma coordenada fundamental de toda a obra poética. Vemos que no teatro grego o tema da justiça é a própria respiração das palavras. Diz o coro de Ésquilo: "Nenhuma muralha defenderá aquele que, embriagado com a sua riqueza, derruba o altar sagrado da justiça”. Pois a justiça se confunde com aquele equilíbrio das coisas, com aquela ordem do mundo onde o poeta quer integrar o seu canto. Confunde-se com aquele amor que, segundo Dante, move o sol e os outros astros. Confunde-se com a nossa fé no universo. (Andresen, 2010, pp. 841-842)

Inerente a essa polaridade da palavra do poeta, está o sentido da justiça. Desde a antiguidade grega, o tema da justiça é a "própria respiração das coisas". Qualquer atentado à justiça era considerado insolência contra os deuses e crime contra os homens. Os próprios deuses intervinham para repor a justiça. A arte era o reflexo dessa ética que reinava na polis e no templum. Esse compromisso ético-moral funda a própria poesia, a sua perseguição interrogativa da realidade. 
Para Sophia, o dizer poético nutre-se das potências da língua e leva a linguagem à sua principal função, a de epifania da verdade imanente. A responsabilidade do escritor e sobretudo do poeta são grandes no que toca ao "sentido". E o texto "Poesia e Revolução" constitui uma espécie de tábua de mandamentos daquele que quer participar na "revolução da Palavra". Buscar a inteireza e a verdade da Presença é a própria essência da poesia, constituindo uma missão infinitamente inacabada; daí, a poesia ser sempre revolucionária, sem ideologia, mas militante da humanidade. Poesia é heterotopia e heterodoxia, génese de "outro lugar", como denota a posição perfilhada por António Ramos Rosa em "Poesia, Liberdade Livre":

A poesia diz sempre mais do que diz, diz outra coisa, mesmo quando diz as mesmas coisas que o resto dos homens e da comunidade. Eis a razáo por que o poeta nunca pode "servir". Ortodoxia e poesia são incompatíveis. Mesmo servindo, não serve; militante embora - de nenhum modo se pretende aqui invalidar tal posiçáo - é, sobretudo, a poesia que ele serve, se é poeta. E só desse modo serve a humanidade. Nesse sentido toda a poesia é militante. (Rosa, 1986, pp. 29-30)

Toda a poesia seria "revolucionária" e "militante", porque ela é desalienação primordial, liberdade primordial e justiça primordial (Andresen, 1977, p.76). A poesia como desalienação procura reencontrar a unidade primeira, a relação harmoniosa e completa com o mundo. A inteireza é o sistema axiológico da verdade, justiça, liberdade, beleza, bem e unidade. Evocar poeticamente um destes valores é nomear a terra-coração onde todos eles se interpenetram e inter-iluminam. Dizer que a poesia procura "o verdadeiro estar do homem na terra" consiste em dizer que procura a relação justa do homem com os outros homens, com a natureza e consigo mesmo. O trabalho poético é, portanto, uma existência comprometida com valores ético-morais.

A poesia está sempre a caminho, não repousa na sua missão de buscar a unidade perdida. Neste sentido, o termo "busca", tanto na sua aceção verbal, como na nominal, repete-se, quase obsessivamente, ao longo de todo o ensaio "Poesia e Revolução". A poesia "busca" os caminhos da inteireza e unidade primordiais. Sophia parece refutar a acusação frequente de que é alvo a arte e que consiste no seu carater secundário para a vida, afirmando o cáracter vital da mesma, reiterando a posição mantida no seu ensaio "Poesia e Realidade” em 1960:

De facto um homem que precisa de poesia, precisa dela, não para ornamentar a sua vida, mas sim para viver.

Precisa dela como precisa de comer ou de beber. Precisa dela como condição de vida, sem a qual tudo é apenas acidente marginal e cinza morta. (Andresen, 1969, p.53) 


\section{Imanência da Verdade}

Ao longo desta reflexão procurámos realçar o teor ético do dizer poético, uma poética-ética do ser. Vimos como o modo de vida do poeta tende a coincidir com o modo de ser do poema, que é um modo de ser onde as coisas se dão na sua transparência. Assim, a vida e a pessoa do poeta são concebidas como um poema encarnado, um poema que se faz carne viva, carne de homem no mundo dos homens. À semelhança da palavra poética, a vida do poeta é chamada a anunciar a luz, a denunciar as opacidades (a injustiça, a mentira, o sofrimento) e a testemunhar sem concessão, sobre o modo da túnica inconsútil da Verdade. Chegamos a um tipo de ética especial do ser poeta. Derivando daí uma definição deontológica e política do poeta: o seu estar é uma tarefa de vida, uma missáo ou uma vocaçấo, a busca integral da verdade. E, mais do que uma busca, é um serviço para com a verdade que se realiza pela palavra. À imagem dos profetas bíblicos, o poeta deve viver e morrer ao serviço da Poesia-Verdade. Habitar poeticamente a terra é talvez um dom, mas é acima de tudo uma responsabilidade infinitamente laboriosa que exige vigilância e atenção contínuas: o amor do Inteiro, no Acontecimento revolucionário da nudez e da luz.

Habitar poeticamente implica, em suma, uma ética fundamental que vincula o sujeito ao desejo de projeto, intensamente intersubjetivo, dialógico ou polifónico. Habitar poeticamente é ser convocado para o futuro e para o sentido (Jesus, 2009, 2013), mediante um labor poético contínuo que visa a própria produção e inteligibilidade de "si mesmo" enquanto espontaneidade vital: afetiva, cognitiva e simbólica (Jesus, 2008).

\section{Bibliografia}

Adorno, T. W. (2000). Metaphysics: Concept and Problems. Stanford: Stanford University Press.

Adorno, T. W. (2005). Negative Dialectics. New York: Continuum.

Adorno, T. W. (1981). Prisms. Cambridge, MA: MIT Press.

Andresen, Sophia. M. B. (2010). Obra Poética. Lisboa: Caminho.

Andresen, Sophia. M. B. (1960). Poesia e Realidade. Colóquio: Revista de Artes e Letras, 8, 52-55.

Andresen, Sophia M. B. (1977). Poesia e Revolução. In O Nome das Coisas (pp. 77-80). Lisboa: Moraes.

Andresen, Sophia. M. B. (1992). O Nu na Antiguidade Clássica. Lisboa: Caminho.

Bambach, C. R. (2013). Thinking the Poetic Measure of Justice: Hölderlin, Heidegger, Celan. Albany: State University of New York Press.

Bernstein, J. M. (2001). Adorno: Disenchantment and Ethics. Cambridge: Cambridge University Press.

Bloch, E. (1995). The Principle of Hope. Cambridge, MA: MIT Press. 
Caygill, H. (2006). Lyric Poetry before Auschwitz. In D. Cunningham \& N. Mapp (Eds.), Adorno and Literature (pp. 69-83). London: Continuum.

Celan, P. (2002). Le méridien et autres proses [édition bilingue]. Paris: Seuil.

Cohen, J. (2005). Interrupting Auschwitz: Art, Religion, Philosophy. New York: Continuum.

France-Lanord, H. (2004). Paul Celan et Martin Heidegger: le sens d'un dialogue. Paris: Fayard.

Giowacka, D. \& Boos, S. (Eds.) (2002). Between Ethics and Aesthetics: Crossing the Boundaries. Albany, NY: State University of New York Press.

Henry, M. (2004). La barbarie. Paris: PUF.

Jesus, M. H. (2014). Regard sur la poésie portugaise contemporaine: gnose et poétique de la nudité. Paris: L'Harmattan.

Jesus, P. (2008). Poétique de l'ipse: étude sur le 'Je pense' kantien. Bern: Peter Lang.

Jesus, P. (2009). L'instabilité de l'être-avec: Configurations de l'intersubjectivité autour de Sartre, Merleau-Ponty et Levinas. Revue philosophique de Louvain, 107(2), 269-300. doi: 10.2143/ RPL.107.2.0000000.

Jesus, P. (2013). Le Moi entre barbarie et messianisme: Critique et jouissance du non-sens comme tâche éthique. In M. Enders \& R. Kühn (Hersg.), Kritik gegenwärtiger Kultur: Phänomenologische und christliche Perspektiven (pp. 233-247). Freiburg: K. Alber Verlag.

Jonas, H. (1984). The Imperative of Responsibility: In Search of Ethics for the Technological Age. Chicago: University of Chicago Press.

Klemperer, V. (2006). Language of the Third Reich: LTI, Lingua Tertii Imperii. London: Continuum.

Lacoue-Labarthe, P. (2004). La poésie comme expérience. Paris: Christian Bourgois.

Marcuse, H. (1998). Eros and Civilization: A Philosophical Inquiry into Freud. London: Routledge.

Nader, A. J. (2007). Traumatic Verses: On Poetry in German from the Concentration Camps, 19331945. Rochester, NY: Camden House.

Rosa, A. R. (1986). Poesia, liberdade livre. Lisboa: Ulmeiro. 